УДК 355.3

Варенья Наталія Михайлівна кандидат юридичних наук, провідний науковий співробітник, Національна академія Служби безпеки України, вул. Михайла Максимовича, 22, м. Київ, 03066, тел.: (044) 527-76-08, e-mail: vareniia@ukr.net, https://orcid.org/0000-0002-2797-197X

Богданов Михайло Васильович заступник завідувача спеціальної кафедри № 15, Національна академія Служби безпеки України, вул. Михайла Максимовича, 22, м. Київ, 03066, тел.: (044) 527-76-08, e-mail: academy@ssu.gov.ua, https://orcid.org/0000-0002-5471-280X

Бондарович Олег Петрович доцент спеціальної кафедри № 15, Національна академія Служби безпеки України, вул. Михайла Максимовича, 22, м. Київ, 03066, тел.: (044) 527-76-08, e-mail: academy@ssu.gov.ua, https://orcid.org/0000-0002-3410-8082

\title{
ПРІОРИТЕТНІ НАПРЯМИ ОРГАНІЗАЦІЇ ФІЗИЧНОЇ ПІДГОТОВКИ ФАХІВЦІВ 3 ПРОТИДІЇ ТЕРОРИЗМУ (ДОСВІД КРАЇН НАТО)
}

Анотація. Вивчення пріоритетних напрямків організації фізичної підготовки спеціалістів правоохоронних органів НАТО на прикладі актуалізації й структурування, узагальнення досвіду провідних країн Північноатлантичного альянсу $є$ перспективним напрямком досліджень у векторах дедалі тіснішої інтеграції України з країнами НАТО й можливим вступом до Альянсу, питання чого активно мусується в сучасній літературі. Метою дослідження був аналіз особливостей фізичної підготовки військовослужбовців та спеціалістів правоохоронних органів, що беруть участь у боротьбі з тероризмом у країнахчленах НАТО. Для реалізації зазначеної мети було використано такі дослідницькі методи: спостереження й опис; метод теоретичного аналізу; аналіз нормативно-правової бази щодо регулювання системи фізичної підготовки; комплексний i диференційований аналіз; функціональний метод; метод системного аналізу; зіставно-проєктувальний; метод узагальнення. У статті охарактеризовано особливості діяльності НАТО, а саме організаційні основи роботи Центрів передового досвіду. Актуалізовано нормативну базу країн-членів НАТО щодо протидії тероризму (зокрема, увагу зосереджено на досвіді Великої Британії та Німеччини). Окрім того, виокремлено пріоритетні напрями організації процесу психофізичної підготовки в США, узагальнено необхідні військово-прикладні рухові навички, що підтверджують фізичну придатність військовослужбовців до опанування й ефективного виконання відповідної військово-професійної діяльності. Подальші дослідження 3 теми доцільно організовувати в напрямку вивчення актуальних напрямів фізичної підготовки спеціалістів НАТО в інших країнах, особливо таких, що активно розвиваються. А 
також доречними будуть експериментальні дослідження 3 питань імплементації досвіду країн НАТО з питань фізичної підготовки правоохоронців безпосередньо в Україні.

Ключові слова: НАТО, тероризм, протидія тероризму, спеціалісти правоохоронних органів, фізична підготовка, військова підготовка, підготовка військовослужбовців.

Varenia Nataliia Mykhailivna Candidate of Science of Law / P.h.D., Leading Researcher, National Academy of Security Service of Ukraine, St. Mikhail Maksimovich, 22, Kyiv, 03066, tel.: (044) 527-76-08, e-mail: vareniia@ukr.net, https://orcid.org/0000-0002-5471-280X

Bohdanov Mykhaylo Vasyl'ovych Deputy head of the special department №15, National Academy of Security Service of Ukraine, St. Mikhail Maksimovich, 22, Kyiv, 03066, tel.: (044) 527-76-08, e-mail: academy@ssu.gov.ua, https:// orcid.org/0000-0002-5471-280X.

Bondarovych Oleh Petrovych Associate professor of the special department № 15, Academy of Security Service of Ukraine, St. Mikhail Maksimovich, 22, Kyiv, 03066, tel.: (044) 527-76-08, e-mail: academy @ ssu.gov.ua, https://orcid.org/0000-0002-3410-8082

\section{PRIORITY DIRECTIONS OF ORGANIZATION OF PHYSICAL TRAINING OF COUNTER-TERRORISM SPECIALISTS (EXPERIENCE OF THE NATO COUNTRIES)}

Abstract. Studying the priority areas of physical training of NATO law enforcement specialists on the example of updating and structuring, summarizing the experience of the leading countries of the North Atlantic Alliance is a promising area of research in the vectors of Ukraine's closer integration with NATO countries and possible entry into the Alliance. The aim of the study was to analyze the specifics of physical training of servicemen and law enforcement officers involved in the fight against terrorism in NATO member countries. To achieve this goal, the following research methods were used: observation and description; method of theoretical analysis; analysis of the legal framework for regulating the system of physical training; complex and differentiated analysis; functional method; method of system analysis; comparative design; generalization method. The article describes the peculiarities of NATO's activities, namely the organizational framework of the Centers of Excellence. The regulatory framework of NATO member countries on counter-terrorism has been updated (in particular, the focus is on the experience of Great Britain and Germany). In addition, the priority areas of organization of the process of psychophysical training in the United States are identified, the necessary military-applied motor skills are summarized, which confirm the physical fitness of servicemen to master and effectively perform the relevant military-professional activities. Further research on the topic should be organized in the direction of studying current areas of physical training 
of NATO specialists in other countries, especially those that are actively developing. Experimental research on the implementation of NATO experience in the field of physical training of law enforcement officers directly in Ukraine will also be relevant.

Keywords: NATO, terrorism, counter-terrorism, law enforcement specialists, physical training, military training, military training.

Постановка проблеми. Одне 3 найголовніших проблемних питань у реформуванні навчальної системи спеціалістів 3 військової справи полягає в тому, щоб розробити й втілити нові технології в галузі фізичної підготовки. Щоб вирішити цю проблему, треба грунтовно проаналізувати різні аспекти фізичного вишколу військовослужбовців передових світових держав. Завдяки такому аналізу вдасться здійснити об'єктивну оцінку переваг і недоліків у підготовці вітчизняних військових порівняно із закордонними._3'ясовано, що чинної системи фізпідготовки ЗСУ недостатньо, а тому професійно-прикладні якості військовослужбовців формуються складніше. Визначивши основні тенденції покращення системи військово-фізичної підготовки у військових структурах провідних держав НАТО, можна буде знайти способи, щоб оптимізувати підготовку українських фахових військовослужбовців, що й надає актуальності цьому дослідженню. Також потребує розгляду питання окреслення обов'язків, які покладаються на фахівців з підготовки спеціалістів правоохоронних органів, що беруть участь у боротьбі з тероризмом, та проаналізувати основні завдання та особливості системи фізичної підготовки військовослужбовців країн-членів HATO.

Аналіз останніх досліджень і публікацій. Дослідженню зазначеного питання свою увагу присвятили такі науковці, як: С. Тимченко, С. Антохін, В. Утенко, К. Лумпиров, Т. Коваленко, Н. Пангелова, В. Щеголєв та ін. Однак дослідження цієї теми не втрачає своєї актуальності у зв’язку з необхідністю удосконалення напрямів фізичної підготовки спеціалістів правоохоронних органів країн-членів НАТО через поширення терористичних явищ у різних країнах світу.

Метою статті $€$ аналіз особливостей фізичної підготовки військовослужбовців та спеціалістів правоохоронних органів, що беруть участь у боротьбі з тероризмом у країнах-членах НАТО.

Для реалізації зазначеної мети було використано такі методи дослідження, як:

- спостереження й опис (при розгляді й описі особливостей структури та змістового наповнення поняття фізичної підготовки правоохоронців НАТО, що працюють з усуненням проявів терористичних загроз);

- метод теоретичного аналізу (при вивченні актуальної літератури з теми та способів теоретичної репрезентації феномену фізичної підготовки спеціалістів правоохоронної діяльності країн НАТО в тематичних розвідках);

- аналіз нормативно-правової бази щодо регулювання системи фізичної підготовки (загальної для всіх країн Альянсу та локально-державних);

- комплексний і диференційований аналіз (під час аналізу поняття фізичної підготовки в контексті діяльності спеціалістів НАТО); 
- функціональний метод (під час визначення поняття фізичної підготовки та ролі його структурних компонентів);

- метод системного аналізу (під час встановлення структурних зв'язків між чинниками фізичної підготовки військових спеціалістів країн НАТО);

- зіставно-проєктувальний (під час порівняння систем підготовки США, Великої Британії, Німеччини та виокремленні напрямів, що можуть бути актуальними для України у світлі перспектив євроатлантичної інтеграції);

- метод узагальнення (під час формування висновків із проведеного теоретичного дослідження).

Виклад основного матеріалу. Свроатлантична інтеграція - один із найважливіших зовнішньополітичних векторів України. Вона необхідна для надійного захисту територіальної цілісності та суверенітету, недоторканності кордонів. Найпотужніший військово-політичний сою3 3-посеред сьогодні наявних - Організація Північноатлантичного альянсу (НАТО). Згідно 3 керівними документами НАТО, у кожного члена альянсу може бути своя система фізпідготовки відповідно до умов та особливостей держави, однак ступінь військової підготовки має відповідати загальним стандартам.

Головне завдання, яке ставить перед собою Північноатлантичний альянс, полягає в тому, щоб захистити свободу й безпеку його членів на території Європи та Північної Америки згідно з принципами, прописаними в статуті ООН. Щоб утілити це завдання, альянс практикує використання як свого політичного впливу, так і військової потужності - залежно від характеру небезпек, з якими стикаються держави-члени НАТО.

Сьогодні НАТО залишається найбільш міцним та послідовним у своїх діях воєнно-політичним блоком. Зважаючи на те, що кордони НАТО впритул наблизилися до кордонів України внаслідок розширення альянсу на схід, стратегія НАТО істотно впливала й впливатиме на формування пріоритетів зовнішньої політики України. Очевидно, що участь України в різноманітних програмах НАТО сприяє, по-перше, активному залученню нашої держави до формування нової євроатлантичної архітектури безпеки, а по-друге, отриманню необхідного для молодої держави досвіду дії в кризовій ситуації [1].

Що стосується підготовки спеціалістів правоохоронних систем, що беруть участь у боротьбі з тероризмом, то в зазначеному напрямку діють Центри передового досвіду НАТО. Вони містять низку окремих відділів, а саме [2]:

1. Захист населення у ході боротьби з тероризмом (DAT).

2. Громадське Військове співробітництво (CIMIC).

3. Суспільний Центр кібернетичної оборони та підвищення кваліфікації.

4. Протидіï саморобним вибуховим пристроям (CIED).

5. Контррозвідка (CI).

6. Ц Центр підвищення кваліфікації з енергетичної безпеки.

7. Ліквідації вибухових речовин (EOD).

8. Агентурної розвідки (HUMINT).

9. Ц ЦПК Стратегічних комунікацій (COE STRATCOM).

10. Кризового управління і реагування на стихійні лиха. 
11. Операцій в холодних погодних умовах (CWO).

12. Об'єднаних спільних операцій з моря (CJOS).

13. Управління та контролю (C2).

14. Центр аналізу та моделювання для підготовки повітряних операцій.

15. Об'єднаних повітряних операціях (JАРCC).

16. Об'єднаний Центр з радіаційного, хімічного, біологічного захисту, РХБЗ (JCBRN).

17. Військово-інженерний (MILENG).

18. Військово-медичний (MILMED).

19. Військової поліції (МР).

20. Моделювання та симуляції (M\&S).

21. Гірсько-піхотний (MW).

22. Військово-морський Центр мінної протидії (NMW).

23. Операцій в умовах обмеженої води та мілководь (CSW).

24. Центр передового досвіду з поліцейської стабільності.

НАТО в контексті протидії тероризму керується такими нормативними положеннями [2]:

1. Військова концепція захисту від тероризму - 2002 (МС-472), що передбачає військові заходи: оборону, управління наслідками, наступальні заходи та співробітництво.

2. Лісабонський саміт: Стратегічна концепція - 2010, що передбачає три основні завдання: колективну оборону, кризовий менеджмент, колективну безпеку.

3. Чиказький саміт: НАТО розроблено керівні вказівки щодо політики у сфері боротьбі з тероризмом та Директиви НАТО щодо контр-терористичної політики - 2012. Він передбачає консультації, обмін розвідувальною інформацією, сумісну роботу експертів та взаємне збагачення найкращими напрацюваннями у пріоритетних векторах роботи.

Реформування української армії за стандартами НАТО $\epsilon$ одним iз найоптимальніших шляхів підвищення рівня іï боєздатності, а відтак i обороноздатності всієї країни. Міністр оборони С. Т. Полторак доповів, що в Збройних силах України вже впроваджено 115 стандартів НАТО. Ще 402 стандарти потребують першочергового впровадження. Такий крок передусім зумовлений курсом на майбутнє членство України в Північноатлантичному альянсі. Війна на Сході країни довела, що позаблоковій державі важко захистити себе в разі агресії сильнішого противника. У цьому контексті варто зважити й на результати останніх опитувань українців, згідно 3 якими вступ до НАТО підтримує понад 60\% громадян України [3].

Командування НАТО за останні 10-12 років неодноразово вживало заходи для підвищення рівня фізичної готовності своїх військ. Інтенсифікація ФП військ провідних країн НАТО досягається по-різному [4]:

- $\quad$ збільшенням службового часу, що відводиться на ФП (у Німеччині - 
до 4,5 годин на тиждень, в армій Франції та ВМС США - до 8 годин на тиждень);

- використанням позаслужбового часу для різних оздоровчих та спортивних програм (програма «Біг заради життя», «Програма президентських нагород»);

стимулюванням досягнення високих результатів через матеріальну зацікавленість (США, Англія) або через масовий спорт (Німеччина, Франція);

- $\quad$ удосконаленням системи планування: в армії США при збереженні ліміту часу на ФП (3 години на тиждень) заняття проводяться щоденно від 15 до 45 хвилин;

- виділенням військово-прикладних вправ у самостійні предмети бойової підготовки: рукопашний бій, курс «Командо» у Франції, курс амфібійної підготовки в США тощо;

- застосуванням сучасних методів тренування: кругового, інтервального та інших;

- удосконаленням матеріальної бази;

- підвищенням вимог та контрольних нормативів, а також ускладненням умов їх виконання. Нормативи підвищуються здебільшого у вправах на базову та спеціальну силову витривалість через збільшення дистанції та кількості повторень (США). У всіх провідних арміях НАТО відпрацьовані таблиці оцінок, які стимулюють підвищення результатів фізичної підготовки.

Головними членами Північноатлантичного альянсу вважають США, Німеччину та Великобританію. Окрім держав, які належать до НАТО, існує низку «супердержав», які перебувають поза військовими блоками, але є дуже значимими на світовій військовій та економічній арені. До таких країн належить Франція. У своєму дослідженні акцентовано проаналізуємо, як організовано фізичну підготовку саме в цих державах.

Для досягнення належного рівня фізичної готовності контингенту командуванням американської армї були розроблені пріоритетні напрями організації процесу психофізичної підготовки [5; 6]:

- розвиток загальної витривалості як основи високої фізичної працездатності та протистояння втомі, що постійно зростає;

- розвиток м'язової сили та витривалості, необхідних для підтримання правильної пози й виконання необхідних обов'язків упродовж тривалого періоду часу;

- $\quad$ формування військово-прикладних рухових навичок: різноманітних способів пересування, долання природних i штучних перешкод, перенесення вантажів, метання гранат, прийомів рукопашного бою;

- розвиток необхідних психічних якостей, навичок самоконтролю в умовах фізичного й психічного стресу;

- забезпечення раціонального зростаючого співвідношення й оптимального складу тіла.

Чинна концепція розвитку Збройних сил США регламентує, що повна фізична готовність передбачає фізичну придатність військовослужбовців до опанування й ефективного виконання відповідної військово-професійної 
діяльності, оволодіння такими військово-прикладними руховими навичками [7]: різноманітні способи пересування - подолання перешкод; виживання у воді; прийоми рукопашного бою; оперативна фізична готовність до ведення бойових дій у конкретних кліматичних умовах.

Також рівень повної фізичної готовності передбачає, що військовослужбовець повинен мати певні морально-вольові якості: бути сміливим, рішучим, упевненим у власних силах, агресивним та здатним діяти в групі й очолити їі.

Згідно $з$ настановою з фізичної підготовки Сил спеціальних операцій ВМС США, під повною готовністю військовослужбовця до бою слід розуміти технічну, психічну й фізичну готовність. Без технічної готовності військовослужбовець не володіє потрібним рівнем військових знань і умінь, без психічної йому бракує впевненості, без фізичної - бракує основних фізичних якостей, щоб виконувати встановлені завдання під час бойових дій» [8, с.57].

Тренувальний процес військовослужбовців заснований на розумному застосуванні загальновідомих принципів: безперервності (поступове, оптимальне підвищення навантажень), прогресування тренувальних впливів (регулярне підвищення фізичного навантаження), збалансованості (гармонійне поєднання видів рухової діяльності), різноманітності, регулярності [9].

1974 року у Збройних силах Великобританії було розроблено абсолютно нову систему фізпідготовки військових, що містила чимало схожого 3 американською системою. Зокрема, подібну концепцію - «фізичну готовність» військових службовців до військової діяльності. Мета фізпідготовки великобританських 3С - забезпечити фізичну здатність військових службовців до виконання бойових завдань. Основні завдання фізпідготовки військовослужбовців:

- підвищувати ефективність професійної роботи;

- скорочувати строки підготовки військ до повної бойової готовності;

- підвищування фізичних показників і зміцнювання здоров’я;

- знімання нервової напруги й активний відпочинок.

Виняткова особливість системи фізпідготовки великобританської армії - це наявність спеціалістів корпусу фізичної підготовки. Вони підпорядковані безпосередньо головному інспекторові фізпідготовки. Для здійснення своїх повноважень їх відряджають до певних військових частин. Оскільки ці частини не містять окремих спеціалістів корпусу фізичної підготовки, вони також не підпорядковані їхнім командирам. Це дає змогу фахівцям зберігати незалежність від командування на місцях.

На спеціалістів покладаються такі обов'язки: здійснення контролю за виконанням програм фізичної підготовки відповідно до вимог керівних документів; періодичне проведення перевірок рівня фізичної готовності особового складу; розробка для командирів та інструкторів з фізичної підготовки рекомендацій щодо удосконалення фізичної підготовки й спортивної роботи. Інакше кажучи, спеціалісти корпусу фізичної підготовки Збройних сил Великобританії виконують роль контролерів і радників з усіх питань організації 
та методики проведення роботи щодо фізичної підготовки й спорту. Така система керівництва й організації фізичної підготовки, на думку англійського командування, створює найбільш ефективні передумови для діяльності спеціалістів фізичної підготовки, спрямованої на забезпечення належного рівня фізичної готовності особового складу всіх родів військ [5; 6;7].

У 1974 році аналіз бойових дій армій США в Кореї та В’єтнамі, а також Франції в Індокитаї й Алжирі мотивував командування Німеччини змінити погляди на фізичну підготовку особового складу як засобу підвищення боєздатності військ, а також стимулював заходи для їі вдосконалення. Унаслідок цього з'явилася розробка нової концепції фізичної підготовки у Збройних силах ФРН. Вона базувалася переважно на засобах і методах спортивного тренування й отримала назву «концепція фізичної придатності» [10].

Згідно з новою концепцією, метою фізичної (спортивної) підготовки у бундесвері $€$ «... виховний вплив на цілісну особистість людини через навчання рухам, зміцнення здоров'я й раціональне використання вільного часу». Основними завданнями спортивної підготовки вважався розвиток фізичних навичок і підвищення спортивних досягнень [6].

Спорт став розглядатися, 3 одного боку, як «чудовий засіб військової підготовки й виховання солдатського духу», а з іншого - як частина загального виховання й освіти, яка не має нічого спільного 3 військово-прикладною спрямованістю. Таке протиріччя цільової установки накладало відбиток на організацію та зміст сучасної фізичної підготовки (спорту) Збройних сил Німеччини [5].

У Збройних силах Німеччини фізична підготовка проводиться у двох формах «службового» й «позаслужбового» спорту. До «службового спорту» належать такі етапи [10]: загальний; особливий; перевірки та оцінки; масових змагань; підготовки спортсменів високої кваліфікації.

Аналізом системи фізпідготовки військовослужбовців Німеччини підтверджується, що найхарактернішими ії ознаками є:

- чіткий організаційний розподіл загальнорозвивальної та оздоровлювальної фізкультури, спорту й фізпідготовки військово-прикладного характеру, що є самостійним предметом військової підготовки;

- компенсування відсутніх штатних спеціалістів з фізичної підготовки, що можуть здійснювати масову підготовку, нештатними;

- використання засобів спортивного спрямування разом 3 уніфікованими програмними вимогами для укомплектування двох головних категорій особового складу (призовники й професіонали-контрактники). Загалом реформи системи фізпідготовки німецьких військ мають на меті частково запозичити французьку модель фізпідготовки (у спортивній доктрині) та англоамериканську, що адаптована до вимог кваліфікованих 3С.

Висновки. На основі узагальнення й порівняння результатів здійсненого нами теоретичного дослідження питання фізичної підготовки правоохоронців НАТО, що працюють в напрямку запобігання й боротьби 3 терористичними загрозами, а також на основі даних досліджень інших авторів [2; 6; 8] ми дійшли висновку, що фізична підготовка в обраних нами для аналізу країнах 
(Великій Британії, США, Німеччині) $є$ такою, що охоплюється бойовою підготовкою правоохоронних органів. Фізична підготовка асоціюється 3 головним фактором набуття технічної й психологічної готовності [3; 4]. Тенденція посилення військово-прикладного спрямування фізичної підготовки у співробітників правоохоронних органів країн-членів НАТО збільшується щороку [9]. Країни мають диференційовані стандарти фізичної підготовки, що залежать від релевантних умов. Однак підготовка військовослужбовців та співробітників правоохоронних органів у всіх них повинна відповідати загальним нормам НАТО для забезпечення спільних цілей. Що й показав аналіз нормативної бази.

Для впровадження фізичної підготовки в середовищі співробітників правоохоронних органів особливу увагу надають розвитку якостей фізичного та психічного характеру, таких як витривалість, стійкість, врівноваженість, сміливість, агресивність, згуртованість тощо [10]. Це досягається комплексами вправ, що пов'язані із загартовуванням відчуттями небезпеки та ризику, командними й індивідуальними видами спорту, зокрема військово-прикладними багатоборствами, орієнтуванням, парашутним спортом, альпінізмом та іншими. Фізичну підготовку розглядають як одну 3 головних складових повної боєготовності, основу для втілення готовності технічного та психічного плану у військах.

Вирішальний аспект пошуку альтернатив для вдосконалення процесу фізичної підготовки кадрового складу Служби безпеки України, складової сектору безпеки й оборони України, - спрямування, засноване на глибинних знаннях та мотиваційних засадах діяльності військових. Підготовка має відбуватися 3 урахуванням психофізіологічних особливостей військовослужбовців та співробітників, стимуляція й закріплення як установки усвідомлення актуалізації питання фізичного загартування, підтриманні стабільності у самостійному піклуванні про своє здоров'я та пов'язаного 3 цим підвищення рівня безпекових компетентностей. Це все безпосередньо впливає на якість виконання службових завдань в межах заходів 3 протидії тероризму, пов'язаних як із належним гарантуванням безпеки суспільства загалом, так i особистої безпеки зокрема. Щодо цього аналіз досвіду провідних країн НАТО дає цінні інсайти, роль яких лише зростає у світлі перспектив інтеграції України з Північноатлантичним альянсом.

\section{תimepamypa:}

1. Північноатлантичний Альянс: Історія, Функції, Структура Та Відносини 3 Україною : Навчальний Посібник Для Студентів Вищих Навчальних Закладів, Слухачів Магістерської Підготовки За Напрямом «Державне Управління» Та Системи Підвищення Кваліфікації Державних Службовців / Кол. Авт.; За Заг. Ред. Проф. Д.І.Дзвінчука. Івано-Франківськ : Місто Нв, 2013. 592 C.

2. НАТО та протидія Тероризму. URL: Https://Nuou.Org.Ua/Assets/Documents/Nato-TaProtidya-Terorizmu.Pdf (Дата Звернення: 17.05. 2021).

3. Тимченко С. Л. Підготовка Військовослужбовців Збройних Сил України За Стандартами НАТО. Проблеми Та Напрями Вдосконалення Підготовки Військових Фахівців 3 Урахуванням Досвіду Антитерористичної Операції У Східних Областях України : XVI Наук.Метод. Конф., Житомир, 25 Травня 2017 Р. : Тези Доповідей / М-Во Оборони України, Житомир. Військ. Ін-Т Імені С. П. Корольова. Житомир : ЖВІ, 2017. 176 С. 
4. Романчук С., Романчук В. Фізична Підготовка В Сухопутних Військах Збройних Сил Провідних Держав НАТО. Молода Спортивна Наука України : Зб. Наук. Пр. 3 Галузі Фіз. Культури Та Спорту / За Заг. Ред. С.Приступи. Львів, 2010. Вип. 14, Т. 2. С. 205-209.

5. Анохін С. Д. Фізична Підготовка В Арміях Провідних Держав НАТО : Навч.-Метод. Посіб. Львів : ЛВІ, 2005. 115 С.

6. Щеголев В. А. Физическая Подготовка Иностранных Армий : Учеб. Пособие. СанктПетербург : МО РФ, 2007. 272 С.

7. Утенко В. Н. Основные Модели Физической Подготовки Иностранных Армий : Дис... Доктора Пед. Наук : 13.00.07. Санкт-Петербург : ВИФК, 2003. 456 С.

8. Лумпиров К. (1992). Подготовка Личного Состава Сил Специальных Операций ВМС США. Зарубежное Военное Обозрение, №9. С. 56-57.

9. Коваленко Т. Г., Коганов, Р. В., Мачулин, П. П. Физическая Подготовка Иностранных Армий : Методические Рекомендации. Волгоград : Изд-Во Волгоградского Гос. Ун-Та, 1998. 33 С.

10. Пангелова Н. Є. Організація фізичної підготовки в арміях провідних країн світу. Вісник Кам'янець-Подільського Наџіонального Університету Імені Івана Огієнка, 2015. Вип. 8. С. 268-274.

\section{References:}

1. Dzvinchuk, D. I. (2013), "Pivnichnoatlantychnyi Alians: Istoriia, Funktsii, Struktura Ta Vidnosyny Z Ukrainoiu : Navchalnyi Posibnyk Dlia Studentiv Vyshchykh Navchalnykh Zakladiv, Slukhachiv Mahisterskoi Pidhotovky Za Napriamom "Derzhavne Upravlinnia" Ta Systemy Pidvyshchennia Kvalifikatsii Derzhavnykh Sluzhbovtsi" [North Atlantic Alliance: History, Functions, Structure And Relations With Ukraine: Textbook For Students Of Higher Education Institutions, Students Of Master's Training In The Field Of "Public Administration" And The System Of Advanced Training Of Civil Servants]. City Of NV, Ivano-Frankivsk. 592 P. [in Ukrainian].

2. "NATO Ta Protydiia Teroryzmu" [NATO and Counter-Terrorism]. URL: Https://Nuou.Org.Ua/Assets/Documents/Nato-Ta-Protidya-Terorizmu.Pdf (Date of Access: 17.05. 2021). [in Ukrainian].

3. Tymchenko, S. L. (2017), "Pidhotovka Viiskovosluzhbovtsiv Zbroinykh Syl Ukrainy Za Standartamy NATO" [Training Of Servicemen Of The Armed Forces Of Ukraine According To NATO Standards]. Problems And Directions Of Improving The Training Of Military Specialists Taking Into Account The Experience Of The Anti-Terrorist Operation In The Eastern Regions Of Ukraine: XVI Scientific Method. Konf., Zhytomyr, May 25, 2017: Abstracts. Ministry Of Defense Of Ukraine. Zhytomyr Military Institute Of Radioelectronics S.P. Korolyov. Zhvi , Zhytomyr. 176 P. [in Ukrainian].

4. Romanchuk S., Romanchuk V. (2010), "Fizychna Pidhotovka V Sukhoputnykh Viiskakh Zbroinykh Syl Providnykh Derzhav NATO" [Physical Training In The Ground Forces Of The Armed Forces Of Leading NATO Countries]. Young Sports Science Of Ukraine: Coll. Science. Etc. In The Field Of Phys. Of Culture And Sports. Ed. E. Attacks. Lviv, 2010. Issue 14, Vol. 2. Pp. 205-209. [In Ukrainian].

5. Anokhin, E. D. (2005), "Fizychna Pidhotovka V Armiiakh Providnykh Derzhav NATO" [Physical Training In The Armies Of Leading NATO]. Training Manual. LVI, Lviv. 115 P. [in Ukrainian].

6. Shchegolev, V. A. (2007), "Fizicheskaya Podgotovka Inostrannykh Armiy. Uchebnoye Posobiye” [Physical Training Of Foreign Armies: Textbook]. MO RF, Saint-Petersburg. 272 p. [in Russian].

7. Utenko, V. N. (2003), "Osnovnyye Modeli Fizicheskoy Podgotovki Inostrannykh Armiy" [Basic Models Of Physical Training Of Foreign Armies]: Dis ... Doctor Ped. Science: 13.00.07. VIFK, Saint-Petersburg. 456 P. [in Russian].

8. Lumpirov K. (1992), "Podgotovka Lichnogo Sostava Sil Spetsialnykh Operatsiy VMS Ssha" [Training Of Special Operations Forces Of The US Navy]. Foreign Military Review. Issue 9. Pp. 5657. [in Russian]. 
9. Kovalenko, T. G., Koganov, R. V., Machulin, P. P. (1998), "Fizicheskaya Podgotovka Inostrannykh Armiy : Metodicheskiye Rekomendatsii" [Physical Training Of Foreign Armies: Guidelines]. Volgograd: Izd-Vo Volgogradskogo Gos. University. 33 P. [in Russian].

10. Pangelova, N. E. (2015), "Orhanizatsiia Fizychnoi Pidhotovky V Armiiakh Providnykh Krain Svitu" [Organization Of Physical Training In The Armies Of The World's Leading Countries]. Bulletin Of Ivan Ogienko National University Of Kamyanets-Podilsky. Issue 8. pp. 268-274. [in Ukrainian]. 